\title{
Interaction Effect of Gender on Academic Procrastination and Achievement Orientation among In-School Adolescents
}

\author{
Chijioke Virgilus Amoke ${ }^{1}$, Moses Onyemaechi Ede ${ }^{2}$, Chizua Elsie Umeano ${ }^{1}$, Chinedu Ifedi Okeke ${ }^{3}$, Sebastian \\ Okechukwu Onah ${ }^{4}$, Malachy Anselm Ezeah ${ }^{1} \&$ John Chidubem Nwaogaidu ${ }^{5}$ \\ ${ }^{1}$ Department of Educational Foundations, Faculty of Education, University of Nigeria, Nigeria \\ ${ }^{2}$ Postdoctoral Fellow, School of Education, Faculty of Education, University of the Free State, South Africa \\ ${ }^{3}$ Host and Head, School of Education, Faculty of Education, University of the Free State, South Africa \\ ${ }^{4}$ Department of Sociology and Anthropology, Faculty of Social Sciences, University of Nigeria, Nigeria \\ ${ }^{5}$ Institute of African Studies, University of Nigeria, Nigeria \\ Correspondence: Sebastian Okechukwu Onah, Department of Sociology and Anthropology, University of Nigeria, \\ Nigeria. Email: sebastian.onah@unn.edu.ng
}

Received: May 12, 2021

doi:10.5430/ijhe.v10n6p202
Accepted: July 30, 2021

Online Published: August 2, 2021

\begin{abstract}
The study investigated the interaction effect gender on academic procrastination and achievement orientation among in-school adolescents. The study adopted a pretest posttest non-equivalent control group quasi-experimental design with a population of 804 SS II students (518 female and 286 males). The sample size of 129 SS II students from Udenu Local Government Area of Enugu State was drawn through purposive sampling technique. Procrastination Assessment Scale for Students (PASS) and Achievement Orientation Questionnaire (AOQ) were used for data collection. Confirmatory factor analysis was used to validate the measures. Internal consistency reliability coefficients of 0.69 and 0.87 for PASS and AOQ were estimated through Cronbach alpha. Mean and standard deviation were used to answer the research questions while ANCOVA and t-test were used to test the hypotheses at 0.05 level of significance. It was found that gender does not significantly have effect on in-school adolescents' academic procrastination and achievement orientation. The researchers recommended that among others that the government at all levels should employ competent educational psychologists/psychotherapists and provide enabling environment and facilities for regular cognitive behavioural change programme for in-school adolescents who may be facing problems with academic procrastination. More so, government agencies and professional bodies whose responsibility is to design and revise curriculum for secondary schools should incorporate and emphasize the use of rational emotive behavioural therapy in secondary schools.
\end{abstract}

Keywords: academic procrastination, achievement orientation, gender, in-school adolescents

\section{Introduction}

Academic procrastination has been found to be common among students. A good number of students manifest delay in academic task (David, Samuels, Rainer, Wang, Marsteller, Mendez, Drew, Craig, Guiard, Guilloux, Artymyshyn, Gardier, Gerald, Antonijevic, Leonardo, \& Hen, 2009). These students prefer deferring what needs to be done until it becomes a persistent behaviour that interferes with daily life despite the negative consequences of delay (Kingsleck, 2013).According to Dryden (2000) this type of delay involves the postponement of initiating or completing a commitment indefinitely which could be referred to as procrastination. This delay is also seen to be the avoidance of doing a task that needs to be done before a certain deadline. The delay can be habitual or intentional even when the consequence is obvious. Procrastination is a household name among college students that they make bold to say (Dryden, 2000).

Procrastination can be classified into situation and disposition (Ferrari, Harriott, Evans, Lecik-Michna, \& Wenger, 1997). Dispositional procrastination is not attached to any specific task. It may be seen as being learnt or seen as exhibited in all forms of behaviour. Dispositional procrastination is said to be learnt by the in-school adolescents. This type of behaviour is not often seen in specific tasks but in life. In-school adolescents exhibit it in all forms of behaviour both in academic tasks and in other areas of life endeavor. Unlike dispositional procrastination, situational 
procrastination apparently refers to the type which has to do with avoidance of specific task such as academic work and performance. It talks about specific task in students' academic life (Ferrari, Harriott, Evans, Lecik-Michna, \& Wenger, 1997). When the school adolescents procrastinate or delay in doing these specific academic tasks or activities, it is referred to as academic procrastination.

Academic procrastination is an act of delaying the beginning or the completion of a timely task (Senecal, Julien \& Guay, 2003). Academic procrastination being lack of interest and reduced effort towards favourable academic activities is bedeviling the global academic space among adolescents (Katz, Eliot \& Nevo, 2014; Kim \& Seo, 2015).

Globally, it was reported that students poor achievement in school is attributed to academic procrastination (Madhan, Kumar, Naik, Panda, Gayathri, \& Barik, 2012), and the high proportion of academic procrastination among secondary school students is has taken a worrisome status (Haghbin, McCaffrey \& Pychyl, 2012). To this end, Solomon and Rothblum (1984) estimated that at least half of all students consistently and problematically procrastinate while Ellis and Knaus (1977) found that the number of students who procrastinate at some point approaches 95\%. As reviewed by Ferrari and Beck (1998), approximately 70\% of US college students engage in frequent procrastination and this occurs regardless of state of origin. Similarly, it was reported that academic procrastination are recurrent among students in different regulation models (Steel, 2007). In same vein, Asikhia (2010) stated that the consistent poor underachievement of students in secondary schools in Nigeria is the impact of academic procrastination. There is doubt that the consequences of academic procrastination are better imagined. The negative and adverse effects are far reaching. It could lead reduced academic achievement, excessive stress and poor quality of life. These students to large extent manifest non-adaptive behaviour of delaying the implementation of their thoughts or plans (Steel, 2007), also, they are found to be vulnerable extreme psychological factors such as ranging from depression, anxiety, disappointment and disturbance (Cassady \& Johnson, 2002; Chabaud, Ferrand, \& Maury, 2010). It disheartening to note that academic procrastination is rampant in secondary schools in Enugu State of Nigeria (Ekurii \& Offiahi, 2018). This is buttressed by high prevalent rate academic procrastination in the schools in Enugu State (Ekurii \& Offiahi, 2018). Furthermore, more than $60 \%$ of students in Nigeria as a result academic procrastination record low achievement (Okoiye, 2011).

The possible reason while they are deeply involved in academic stress is because of unjustified belief that they cannot pass examination without help. Most of them agreed that they delay in their academic activities because help must certainly come during their examination. More so, it was reported that students have negative disposition and attitudes towards academic tasks (Ekurii \& Offiahi, 2018). Some of the reasons according to them include online games, social media (Ocak \& Boyraz, 2016), betting for sports, hawking, cashew picking, among others. They do these things at the expense of their academic tasks leading to a delay in task completion, disturbed sleep, stress, and anxiety to manage time (Bashir, Bashir, \& Nazir, 2015). It is very glaring that academic procrastination cannot be dissociated from ones achievement orientation.

Achievement orientation is the standard that the individuals set that influences their actions, reactions, and motivations for learning and accomplishing a goal (Shim \& Ryam, 2005). Achievement orientation is the beliefs, values, standards, practices and norms that guide and regulates one's academic pursuit. Achievement orientation depicts the way and manner students understand, interpret and respond to academic tasks (McGrew, 2008; Odinaka, 2016). Achievement orientation are broadly categorized into high and low (Johnson, 2009). High achievement orientation is motivational and encourages success of an individual. High achievement orientation is goal-directed as a result of personal efforts and environmental influence (Johnson, 2009). The characteristic feature of high academic orientated student is circumscribed in value competence, success expectation and frontal confrontation of challenges in the task areas towards actualization. On the contrary, in-school adolescents with low achievement orientation do not make improvement towards their desired goals as they exhibit negative orientation towards genuine achievement (Johnson, 2009). Students with low achievement orientation are prone to poor self-awareness and performance of life goal (Omeje, 2007). More so, low achievement oriented students avoid hard work. It is on record that some students lack the achievement orientation towards academic success (Kaplan, Middletion, Urdan \& Midgby, 2004). While reasonable number of the students who do not sufficient orientation tend to serious academic responsibilities (Kaplan, Middleton \& Midgley, 2004).

From the observation of the researcher, the students in this area of study, awfulize and overgeneralize goal setting and decision-making leading to unrealistic goals. This has consistently affected their values and commitment towards academic engagements. Some have low frustration tolerance and self-defeating syndrome which dissuade them from active academic engagement. As a result, they lack the resilience and persistence that orientation would have offered in order to get them directed and focused in their academic obligations. Currently, in Enugu state, students' low 
achievement orientation seems to be increasing. Some of the student's exhibit nonchalant attitude towards their academic tasks especially their take home- assignments. This is corroborated with earlier submission that pronounced lack of achievement orientation has dwindled students' performance (Efklides \& Dina, 2007) and this is most common among in-school adolescents in secondary schools in the area of the study with emphasis on gender related factors (Idankwo, 2011).

Gender being a socio-cultural factor can influence student's academic performance (Nnachi, 2010). This is because male and female students may not behave and think alike even in the setting. There is a high likelihood that males and females experience irrational belief, fears and distorted thoughts, academic procrastination and achievement orientation among differently or in likewise manner. However some studies reported significant gender difference in academic endeavours (Pychl, Coplan \& Reid, 2002) while other studies reported no such gender difference (Ferrari, 2001). Nevertheless in this study, it is possible that gender could mediate the manifestations of some variables such as achievement orientation and academic procrastination among in-school adolescents. These manifestations of lack of achievement orientation and academic procrastinations are behavioural problems which may be addressed through behavioural interventions.

\section{Rational Emotive Behavioural Intervention}

One of such behavioural intervention strategies that may enhance reduce academic procrastination and enhance achievement orientation is Rational Emotive Behavoural Therapy developed by Albert Ellis in 1955. The more irrational belief in an individual the more an individual will be vulnerable to psychological disturbances whether the belief comes from social or biological factor. By using this therapy the researcher hopes to adjust the maladaptive behaviours that academic procrastination may bring among in-school adolescents such as avoidance of classes, truancy and avoidance of academic task that makes the in-school adolescents not to be properly motivated intrinsically in doing any academic task for a positive outcome in life. The goal of REBT therapy is best seen as method that disputes and challenges irrational and dysfunctional belief and replacing them with sensible roles and functional beliefs (Agah et al 2020; Agah et al 2021, Ifeanyieze et al 2021; Iremeka et al 2021; Onyishi et al 2020; Ugwuanyi et al 2020a; Ugwuanyi et al 2020b).

Rational emotive behavioural therapy is an insight behaviourial procedure that emphasizes recognizing and changing negative thoughts and maladaptive belief (Salman, Esere, Omotosho, Abdullahi, \& Oniyangi, 2010). These interventions are done through replacement, rehearsal, counselling, giving homework making connection with body feeling, and the environment to help clarify life value and make plans to pursue life goals and make commitment to actions by psychological therapies and cognitive-oriented therapies in clarifying life values and goals, past studies also suggested that the therapies could help in cushioning unhealthful psychological effects of procrastination and low achievement orientation among student population. Furthermore, rational emotive behavioural therapy has been widely used to solve many life problems with successful evidence (Onyechi, 2016). Rational emotive behavioural therapy was previously effective in reducing negative thoughts and irrational beliefs among students in Enugu State (Abiogu et al 2020a; Abiogu et al 2020b; Abiogu et al 2021a; Ede et al 2020a; Ede et al 2020b; Ede et al 2021a; Ogbuanya, et al 2017b). Rational emotive behaviour therapy was also effective in leadership training and acquisition of life skills (Grieger \& Fralick, 2007).

Based on these reasons, the researchers hypothesized to find out the interaction effect of gender on academic procrastination and achievement orientation among in-school adolescents in Enugu State, Nigeria.

\section{Methods}

The study adopted quasi-experimental design specifically, pretest posttest non-equivalent control group design. According to Nwogu (2015) quasi-experimental non-equivalent design is a type of experiment design in which participants are not randomly assigned to groups. The experimental groups received rational emotive behavoural therapy intervention programme while the control group were given the conventional counselling programme based on examination malpractice. The reason for the use of quasi-experiment design in this study is based on non-randomization of the subjects since intact classes were used. It will also help not to disrupt the normal class structure activities.

The population of the study comprised all the 804 SS II students (518 female and 286 males) Planning Research and Statistics Unit Post Primary School Management Board (PPSMB) Udenu Local Government Area. The sample for the study was 129 SS II students of Udenu Local Government Area of Enugu State. Purposive sampling technique was used to draw two co-educational schools among the 16 secondary schools in Udenu Local Government Area. The researcher used the co-educational school to take care of the gender factor. Procrastination Assessment Scale for 
Students (PASS) and Achievement Orientation Questionnaire (AOQ) were used to identify students who are involved in academic procrastination and low achievement orientation from the study area. The choice of SS II students is based on their age which is often an adolescent age.

Procrastination Assessment Scale for Students (PASS) developed by Solomon and Rothblum, (1984) is a 27-item self-report scale, adapted by the researcher. The researcher modified the instrument since it was developed in different cultural setting. PASS aimed at assessing students' belief, thinking and assumptions about academic tasks leading to procrastination. The instrument consists of three sections A, B and C. Section A elicited the demographic characteristics of the participants namely, treatment identification number, class, sex, parental occupation, parents' marital status, state of origin, and age. Section B identified clinical/psychological characteristics namely length of the condition, severity of the condition, and duration of condition. Besides the items of the instrument adapted from Solomon and Rothblum, (1984), a good number of studies were reviewed to build up the demographic and clinical characteristics of the participants (Ede et al, 2020a; Nwokeoma et al, 2019a). The authors argued that in clinical case like this, psychological/clinical characteristics are required to understand possible predictors of the condition. Sections C measures students' academic procrastination. The items are rated on a four-point scale of Strongly Agree (4) Agree (3) Disagree (2) and Strongly Disagree.

Achievement Orientation Questionnaire (AOQ) developed by was (2006) 34-item scale aimed at measuring achievement orientation. The AOQ was adopted by current researcher since the language in the instrument was not ambiguous for the participants to comprehend. AOQ consists of two sections. Section A seeks information on the demographic data of the participants. Section B consists of 33 items put into four subscales namely mastery (13 items), performance approach (8 items), performance avoidant (7 items), and work avoidant (5 items). The items of instrument were rated on a six-point Likert scale of Very Untrue, Mostly Untrue, Somewhat Untrue, Somewhat True, Mostly True and Very True. Confirmatory factor analysis was used to validate the two instruments which revealed that they have Eigen values above 2.50 in order to accommodate the students from the local. The internal consistency reliability through Cronbach alpha yielded coefficients of 0.748 and 0.895 for PASS and AOQ respectively. However, previous studies have tested the reliability and validity of PASS in different cultures namely USA ( $\alpha-0.82$, 0.89) (Onwuegbuzie, 2004), Turkey $(\alpha=0.70)$ (Ferrari, 1989), Turkey $(\alpha=0.87)$ (Ozer \& Ferrari, 2011). For the present sample, Cronbach alpha coefficients were 0.69 and 0.87 for the first and the second part of the scale, respectively.

The treatment lasted for six weeks. In the first week, there were cognitive alliance and familiarization, identification of procrastination and low academic orientation activating events. The second week was on the identification beliefs students have. Week three consequences were identified. In week four and five, there were disputes on those irrational beliefs and replacing with rational beliefs. Finally, there feelings were identified based of the disputations. The control group received normal counselling programmes for the same six weeks. Two volunteered qualified school trained research assistants helped in administering the treatment packages. The data collected were analyzed using mean and standard deviation while analysis of covariance (ANCOVA) was used to test the hypotheses at 0.05 level of significance.

\section{Results}

Table 1. Interaction effect of treatments and gender on mean academic procrastination scores

\begin{tabular}{lllll}
\hline Groups & Gender & N & Mean & Std. Dev. \\
\hline Experimental Group (REBT) & Male & 24 & 50.33 & 15.40 \\
& Female & 37 & 52.92 & 14.29 \\
Lecture Method (Control Group) & Male & 29 & 58.45 & 15.37 \\
& Female & 39 & 61.23 & 10.92 \\
\hline
\end{tabular}

Result of the analysis in Table 1 revealed that male in-school adolescents exposed to experimental group (REBT) had lower mean academic procrastination scores of 50.33 and a standard deviation of 15.40 as against their male counterparts in the lecture method that had a mean academic procrastination scores of 58.45 with standard deviation of 15.37. On the other hand, female in-school adolescents exposed to experimental group (REBT) also had lower mean academic procrastination scores of 52.92 and a standard deviation of 14.29 while their female counterparts in the lecture method had a mean academic procrastination scores of 61.23 with standard deviation of 10.092 . 
Table 2. Distribution of male and female in-school adolescents on academic procrastination scores

\begin{tabular}{llllllll}
\hline Gender & N & Pre-test & & Post-test & & $\begin{array}{l}\text { Mean Gain } \\
\text { Scores }\end{array}$ & $\begin{array}{l}\text { Mean Gain } \\
\text { Difference }\end{array}$ \\
& & Mean & SD & Mean & SD & & \\
\hline Male & 53 & 133.06 & 33.02 & 152.96 & 20.37 & 19.90 & 1.09 \\
Female & 76 & 130.95 & 19.50 & 149.76 & 14.34 & 18.81 & \\
\hline
\end{tabular}

Result of the analysis in Table 2 revealed that at pre-test, male in-school adolescents had mean academic procrastination ratings of 133.06 with a standard deviation of 33.02 while their female counterpart had mean academic procrastination ratings of 130.95 with standard deviation of 19.50. At post-test, male in-school adolescents had mean academic procrastination ratings of 152.96 and standard deviation of 20.37 while female in-school adolescents had mean academic procrastination ratings of 149.76 with standard deviation of 14.34. The mean gain ratings of the males were 19.90 while the mean gain score of the female in-school adolescents was 18.81 . The results therefore, show that gender may influence in-school adolescents' academic procrastination. This can be seen from a very slight mean gain score difference of 1.09 in favour of the male in-school adolescents.

Table 3. Interaction effect of treatments and gender on mean achievement orientation scores

\begin{tabular}{lllll}
\hline Groups & Gender & N & Mean & Std. Dev. \\
\hline Experimental Group (REBT) & Male & 24 & 160.17 & 24.89 \\
& Female & 37 & 152.19 & 15.88 \\
Lecture Method (Control Group) & Male & 29 & 147.00 & 13.43 \\
& Female & 39 & 147.46 & 12.47
\end{tabular}

Result of the analysis in Table 3 revealed that male in-school adolescents exposed to experimental group (REBT) had higher mean achievement orientation scores of 160.17 and a standard deviation of 24.89 as against their male counterparts in the lecture method that had a mean achievement orientation scores of 147.00 with standard deviation of 13.43. On the other hand, female in-school adolescents exposed to experimental group (REBT) had higher mean achievement orientation scores of 152.19 and a standard deviation of 15.88 while their female counterparts in the lecture method had a mean achievement orientation scores of 147.46 with standard deviation of 12.47 .

Table 4. Conventional method on in-school adolescents' academic procrastination

\begin{tabular}{llllll}
\hline Source & Type III Sum of Squares & df & Mean Square & F & Sig. \\
\hline Corrected Model & $2378.402^{\mathrm{a}}$ & 4 & 594.600 & 3.080 & .019 \\
Intercept & 5288.562 & 1 & 5288.562 & 27.393 & .000 \\
PretestAP & 20.432 & 1 & 20.432 & .106 & .745 \\
Method & 2101.570 & 1 & 2101.570 & 10.885 & .001 \\
Gender & 225.365 & 1 & 225.365 & 1.167 & .282 \\
Method * Gender & .079 & 1 & .079 & .000 & .984 \\
Error & 23939.753 & 124 & 193.063 & & \\
Total & 433667.000 & 129 & & & \\
Corrected Total & 26318.155 & 128 & & &
\end{tabular}

The Table shows that gender is not a significant factor on in-school adolescents' academic procrastination; $F(1,124)$ $=1.167, \mathrm{P}=.282$. Thus, the null hypothesis of no significant difference was accepted because the exact probability level of .282 was greater than level of significance set at 0.05 . The researcher therefore, concludes that there is no significant difference in the mean academic procrastination ratings of male and female in-school adolescents.

The Table shows that the exact probability value of .984 associated with methods and gender was greater than 0.05 level of significance; $(\mathrm{F}(1,124)=.000, \mathrm{P}=.984)$. Thus, the null hypothesis of no significant interaction effect of methods and gender on in-school adolescence' academic procrastination was accepted. The researcher therefore, 
concludes that the interaction effect of teaching methods and gender on in-school adolescence' academic procrastination was not significant.

Table 5. Conventional method on in-school adolescents' achievement orientation

\begin{tabular}{|c|c|c|c|c|c|}
\hline Source & Type III Sum of Squares & & Mean Square & $\mathrm{F}$ & Sig. \\
\hline Corrected Model & $4800.499^{\mathrm{a}}$ & 4 & 1200.125 & 4.577 & .002 \\
\hline Intercept & 82293.133 & 1 & 82293.133 & 313.876 & .000 \\
\hline PretestAOQ & 1779.976 & 1 & 1779.976 & 6.789 & .010 \\
\hline Method & 2240.450 & 1 & 2240.450 & 8.545 & .004 \\
\hline Gender & 367.031 & 1 & 367.031 & 1.400 & .239 \\
\hline Method * Gender & 567.770 & 1 & 567.770 & 2.166 & .144 \\
\hline Error & 32510.726 & 124 & 262.183 & & \\
\hline Total & 2981661.000 & 129 & & & \\
\hline Corrected Total & 37311.225 & 128 & & & \\
\hline
\end{tabular}

Result of the analysis in Table above shows that conventional method is not a significant factor on in-school adolescents' achievement orientation; $\mathrm{F}(1,124)=8.545, \mathrm{P}=.004$. Thus, the null hypothesis of no significant difference was rejected. This is because the exact probability value (.004) is less than the level of significance set at 0.05 .

The result shows that gender is not a significant factor on in-school adolescents' achievement orientation; F $(1,124)$ $=1.400, \mathrm{P}=.239$. Therefore, the null hypothesis of no significant difference was accepted because the exact probability level of .239 is greater than level of significance set at 0.05 . The researcher therefore, concludes that there is no significant difference in the mean achievement orientation ratings of male and female in-school adolescents.

The Table shows that the exact probability value of .144 associated with methods and gender is greater than 0.05 level of significance; $(\mathrm{F}(1,124)=2.166, \mathrm{P}=.144)$. Thus, the null hypothesis of no significant interaction effect of teaching methods and gender on in-school adolescence' academic procrastination was accepted. The researcher therefore, concludes that the interaction effect of teaching methods and gender on in-school adolescence' achievement orientation was not significant

\section{Discussion of Findings}

The findings of the study revealed that gender did not significantly influence academic procrastination of in-school adolescents. The result indicated that Rational Emotive Behaviour Therapy (REBT) technique reduces both male and female in-school adolescents' academic procrastination. This implies that male and female in-school adolescents benefited equally from the treatment. This outcome agreed with past studies conducted by Nwokeoma et al (2020b) and Obiweluozo et al (2021) that REBT-interventions are powerful method to reduce unrealistic behaviours and feelings. The result of the study agrees with the findings that gender was not a significant predictor of academic procrastination and orientation among students (Ozer \& Ferrari, 2011). However, the findings of the study are in disagreement with the findings of Khan, Arif, Noor and Muneer (2014) who found a significant difference among males and females on academic procrastination. Also, in disagreement was the finding of Shahnawaz (2016) who found that gender is a significant predictor of procrastination and males were found to be higher on procrastination and perfectionism than females.

The findings of the study with respect to the interaction effect of teaching methods and gender on academic procrastination of in-school adolescents revealed no significant interaction effect of teaching method and gender. The result implies that in-school adolescents' academic procrastination across gender was consistent. This is an indication that both male and female students benefited significantly from the strategy used. The study is in agreement with findings of Dryan and Levin (1995) who reported no significant interaction effect treatment and gender. The findings of Omebe and Omiko (2015) who found no significant interaction effect between treatment and gender on students' achievement. The result however disagrees with the findings of Eraikhuemen (2003) that reported significant interaction effect of gender and school location on the academic achievement of students. 
The findings of the study revealed no significant interaction effect of teaching methods and gender on achievement orientation of in-school adolescents. The result indicates that in-school adolescents' achievement orientation across gender was consistent. This is an indication that both male and female students benefited significantly from the methods used. The no significant interaction effect of methods and gender may have resulted from exposing the students to active participation without gender discrimination which was aides with the intervention of rational emotive behavioural therapy. This implies that the contribution of gender on the effect of treatment on the dependent measures was not significant. The findings of the study in agreement with the finding of Miriogu (2012) and Agomuoh (2010) who found no interaction effect of gender and instructional treatment. Nevertheless, the result of the study contradicts with the finding of Baser (2006) who found that gender significantly interacts with the instructional treatment. The result of the study lends credence to the theoretical opinion of Beck (1999) that both male and female learn to recognize negative patterns of thought, evaluate their validity, and replace them with healthier ways of thinking. The study of Musa, Dauda and Umar (2016) corroborated this finding that gender does not significantly influence achievement orientation.

\section{Conclusions}

Based on the analysis and interpretation of the results obtained, it is concluded that gender do not significantly influence the effectiveness of rational emotive behavioural therapy in reducing cognitive symptoms of depression as well as enhancing achievement orientation of in-school adolescents. The interaction effect of teaching methods and gender on in-school adolescence' academic procrastination and achievement orientation were not significant.

\section{Recommendations}

Considering the findings of the study, the following recommendations were made by the researcher:

1) The government at all level should employ competent educational psychologists/psychotherapists and provide enabling environment and facilities for regular cognitive behavioural change programme for in-school adolescents who may be facing problems with academic procrastination.

2) Government agencies and professional bodies whose responsibility is to design and revise curriculum for secondary schools should incorporate and emphasize the use of rational emotive behavioural therapy in secondary schools.

3) The focus of rational emotive behavioural therapy could be expanded beyond that of the in-school adolescent to adult learner and to also consider social, political, and cultural contexts. This is because; learners are influenced by the surrounding contexts which shape their thinking and action.

\section{References}

Abiogu, G. C., Ede, M. O., Agah, J. J., Ugwuozor, F. O., Nweke, M., Nwosu, N., Nnamani, O., Eskay, M., Obande-Ogbuinya, N. E., Ogheneakoke, C. E., Ugwu, U. C., Ujah, P., Ekwueme, F. O., Obeagu, E. I., Okeke, C. I., Ncheke, D. C., \& Ugwuanyi, C. (2020a). Cognitive-behavioural reflective training for improving critical $\begin{array}{lllll}\text { thinking disposition of nursing students. Medicine, } & \text { 99(46), } & \text { e22429. }\end{array}$ https://doi.org/10.1097/MD.0000000000022429

Abiogu, G. C., Ede, M. O., Agah, J. J. et al (2021a). Effects of rational emotive behavior occupational intervention on perceptions of work value and ethical practices: Implications for educational policy makers. Journal of Rational-Emotive and Cognitive-Behavior Therapy. https://doi.org/10.1007/s10942-021-00389-0

Abiogu, G. C., Ede, M. O., Amaeze, F. E., Nnamani, O., Agah, J. J., Ogheneakoke, C. E., Ugwuozor, F. O., Obiyo, N., Ezurike, C., Nwosu, N., Onyeanusi, O. C., Nweke, M. L., Amoke, C. V., Asogwa, T. E., Obeagu, E. I., \& Ede, K. R. (2020b). Impact of rational emotive behavioral therapy on personal value system of students with visual impairment: A group randomized control study. Medicine, 99, 45, e22333. https://doi.org/10.1097/MD.0000000000022333

Agah, J. J., Ede, M. O., Zudonu, O. C., Asor, L. J., \& Onyishi, C. N. (2020).Testing the efficacy of the FEAR-Model of cognitive behavioural therapy in treating test anxiety in Chemistry students. Journal of Rational-Emotive \& Cognitive-Behavior Therapy. https://doi.org/10.1007/s10942-020-00376-x

Agah, J. J., Ede, M. O., Asor, L. J., \& Ejionueme, L. T. (2021). Managing examination induced stress among students using FEAR-model of cognitive behavioural intervention: Policy implications for educational evaluators. Current Psychology. https://doi.org/10.1007/s12144-021-01657-z 
Amoke, C. V., Ede, M. O., Nwokeoma, B. N., Onah, S. O., Ikechukwu-Ilomuanya, A. B., Albi-Oparaocha, F. C., Nweke, M. L., Amoke, C. V., Amadi, K. C., Aloh, H. E., Anyaegbunam, E. N., Nwajiuba, C. A., Onwuama, O. P., Ede, K. R., Ononaiwu, A. I., \& Nweze, T. (2020). Effects of group cognitive-behavioral therapy on psychological distress of awaiting trial prison inmates. Medicine, 99(17), e18034. https://doi.org/10.1097/MD.0000000000018034

Asikhia O. A. (2010). Students and teachers' perception of the causes of poor academic performance in Ogun State Secondary Schools. Euro. J. Soc. Sci, 13(2), 229-242.

Bashir, S., Bashir, Z., \& Nazir, M. (2015). Time management and its application in academic life: a study of omani students at Dhofar university, sultanate of Oman. Linguistics, 4(2), 154-159.

Beck, A. T. (1999). Prisoners of hate: The cognitive basis of anger, hostility and violence. New York: Harper Collins Publishers.

Cassady, J. C., \& Johnson, R. E. (2002). Cognitive test anxiety and academic performance. Contemporary Educational Psychology, 27(2), 270-295. https://doi.org/10.1006/ceps.2001.1094

Chabaud, P., Ferrand, C., \& Maury, J. (2010). Individual differences in undergraduate student athletes: The roles of perfectionism and trait anxiety on perception of procrastination behavior. Social Behavior and Personality: An International Journal, 38(8), 34-49. https://doi.org/10.2224/sbp.2010.38.8.1041

David, D. J., Samuels, B. A., Rainer, Q., Wang, J. W., Marsteller, D., Mendez, I., Drew, M., Craig, D. A., Guiard, B. P., Guilloux, J. P., Artymyshyn, R. P., Gardier, A. M., Gerald, C., Antonijevic, I. A., Leonardo, E. D., \& Hen, R. (2009). Neurogenesis-dependent and -independent effects of fluoxetine in an animal model of anxiety/depression. Neuron, 62, 479e493. https://doi.org/10.1016/j.neuron.2009.04.017

Dryden, W. (2000). Overcoming procrastination. London: Sheldon Press.

Ede, M. O., Adene, F. M., Okeke, C. I., Mezieobi, D. I., Isiwu, E. N., \& Abdullahi, Y. (2021). The effect of rational emotive behaviour therapy on post-traumatic depression in flood victims. Journal of Rational-Emotive \& Cognitive-Behavior Therapy. https://doi.org/10.1007/s10942-021-00401-7

Ede, M. O., Anyanwu, J. I., Onuigbo, L. N., Ifelunni, C. O., Alabi-Oparaocha, F. C., Okenyi, E. C., Agu, M. A., Ugwuanyi, L. T., Ugwuanyi, C., Eseadi, C., Awoke, N. N., Nweze, T., \& Victor-Aigbodion, V. (2020a). Rational emotive family health therapy for reducing parenting stress in families of children with autism spectrum disorders: A group randomized control study. Journal of Rational-Emotive \& Cognitive-Behavior Therapy, 38, 243-271. https://doi.org/10.1007/s10942-020-00342-7

Ede, M. O., Omeje C. J., Ncheke, D. C., Agah, J. J., Chinweuba N. H., \& Amoke, C. V. (2020b). Assessment of the effectiveness of group cognitive behavioural therapy in reducing Pathological Gambling. Journal of Gambling Studies. https://doi.org/10.1007/s10899-020-09981-y

Efklides, A., \& Dina, F. (2007). Is mastery orientation always beneficial for learning? In F. Salili \& R. Hoosain (Eds.): Culture, motivation and learning: A multicultural perspective (pp. 131-67). Greenwich, CT: Information Age Publishing.

Ekurii, E. E., \& Offiahi, C. I. (2018). Self-Regulatory attributes and academic performance in mathematics among secondary school students in Enugu education zone, Enugu state. International Journal of Scientific Research in Education, 11(3), 455-466.

Ellis, A. (1955). New approaches to psychotherapy techniques. Journal of Clinical Psychology, 11, $207-260$. https://doi.org/10.1002/1097-4679(195507)11:3<207::AID-JCLP2270110302>3.0.CO;2-1

Ellis, A., \& Knaus, W. J. (1977). Overcoming procrastination. New York: Institute for Rational Emotive Behavioural Therapy.

Ferrari, J. R., Harriott, J. S., Evans, L., Lecik-Michna, D. M., \& Wenger, J. M. (1997). Exploring the time preferences by procrastinators: Night or day, which is the one? European Journal of Personality, 11(3), $187-196$. https://doi.org/10.1002/(SICI)1099-0984(199709)11:3<187::AID-PER287>3.3.CO;2-Y

Ferrari, J. R. (2001). Procrastination and attention factor analysis of affection deficit, boredomness, intelligence, self-esteem and task delay frequencies. Journal of social behaviour and personality, 16, 185-196.

Grieger, R., \& Fralick, (2007). The use of REBT principles and practices in leadership training and development. Journal of Rational-Emotive and Cognitive-Behavior Therapy, 25(2), 143-154. 
https://doi.org/10.1007/s10942-006-0038-x

Haghbin, M., McCaffrey, A., \& Pychyl, T. A. (2012). The complexity of the relation between fear of failure and procrastination. Journal of Rational-Emotive \& Cognitive-Behavior Therapy, 30(4), 249-263. https://doi.org/10.1007/s10942-012-0153-9

Idankwo, N. M. (2011). The use of social media among Nigerian youths www.slideshare.net/goldlami/the-use-of-social-media-networks-among-nigerianyouths. (Retrieved 26/7/2012).

Ifeanyieze, F. O., Ede, M. O., Ejiofor, T. E., Ekenta, L. U., Onah, O., Okechukwu, F. C., Isiwu, E. C., Ogbonna, E., Azunku, F., Nwankwo, C. U., Ezebuiro, F., Onah, F. C., Mezieobi, D. I., Ede, K. R., Onyeanusi, O. C., Asogwa, V. O., Omeje, B., Abubakar, I., \& Samuel, M. (2021). Irrational career beliefs in agricultural education students, demographics, impacts, and rational career education intervention. Medicine, e26168. https://doi.org/10.1097/MD.0000000000026168

Iremeka, F. U., Ede, M. O., Amaeze, F. E., Okeke, C. I., Ilechukwu, L. C., Ukaigwe, P. C., Wagbara, C. D., Ajuzie, H. D., Isilebo, N. C., Ede, A. O., Ekesionye, N. E., Okeke, P., Okoronkwo, O. L., Okengwu, M. C., Chigbu, B., Ejionueme, L. K., Agu, P. U., Ezeaku, F., \& Aneke, M. (2021). Improving work-life balance among administrative officers in Catholic primary schools: Assessing the effect of a Christian religious rational emotive behavior therapy. Medicine, 100(24), e26361. https://doi.org/10.1097/MD.0000000000026361

Johnson, D. W. (2009). Reaching out: interpersonal effectiveness and self-actualization (10 ${ }^{t}$ Edition).

Katz, I., Eilot, K., \& Nov, N. (2014). "I II do it later". Type of motivation, self-efficacy and homework procrastination. Motivation and Emotion, 38 (1), 111-119. https://doi.org/10.1007/s11031-013-9366-1

Khan, Arif, Noor, \& Muneer, R. (2014). Academic procrastination among male and female university and college students.

Khan, Arif, Noor, \& Muneer (2014) aimed to investigate the academic procrastination among male and female university and college students.

Kim, K. R., \& Seo, E. H. (2015). The relationship between procrastination and academic performance: A meta-analysis. Personality and Individual Differences, 82, 26-33. https://doi.org/10.1016/j.paid.2015.02.038

Klingsieck, K., Grund, A., Schmid, S., \& Fries, S. (2013) Why Students procrastinate: A qualitative approach. Journal of College Student Development, 54(4), 397-412. https://doi.org/10.1353/csd.2013.0060

Klingsieck, K. B. (2013). Procrastination: When good things don't come to those who wait. European psychologist, 18(1), 24-34. https://doi.org/10.1027/1016-9040/a000138

Madhan, B., Kumar, C. S., Naik, E. S., Panda, S., Gayathri, H., \& Barik, A. K. (2012). Trait procrastination among dental students in India and its influence on academic performance. Journal of Dental Education, 76(10), 1393-1398. https://doi.org/10.1002/j.0022-0337.2012.76.10.tb05397.x

McGrew, K. S. (2008). Beyond IQ: Model of academic competence and motivation (MACM) overview and definition. Retrieved on April $4^{\text {th }} 2011$ from http://www.slideshare.net/iapsych/macm-overview

Musa, A. K. J., B Dauda, B., \& Umar, M. A. (2016). Gender difference in achievement goals and performance in English Language and Mathematics of senior secondary schools students in Borno State, Nigeria. Journal of Education and Practice, 7(27).

Nnachi, R. O. (2010). Gender equity in education: A challenge to school system in the Igbo speaking states of Nigeria. JONAED, 6(1), 102-116.

Nwokeoma, B. N., Ede M. O., Nwosu, N., Ikechukwu-Illomuanya, A., Ogba, F. N., Ugwoezuonu, A. U., Offordile, E. E., Agu, P. U., Amoke, C., Eze, C. O., Nnamani, O., Nwafor, B., Omeke, F. C., Omeje, G. N., Vita-Agundu, U. C., Onuh, E. A., Okorie, C. O., Ede, K. R., \& Nwadike, N. (2019). Impact of rational emotive occupational health coaching on work-related stress management among staff of Nigerian Police Force. Medicine, 98(37), e16724.

Nwokeoma, B. N., Ede, M. O., Ugwuanyi, C., Mezieobi, D., Ugwoezuonu, A. U., Amoke, C., Egenti, N. T., Nwosu, N., Oforka, T. O., Victor-Aigbodion, V., Offordile, E. E., Ezeh, N. E., Eze, C. O., Eluu, P. E., Ugwuanyi, B. E., Uzoagba, N. C., Ugwonna, G. O., Chukwu, C. L., Amadi, K. C., \& Eseadi, C. (2019a). Efficacy of prison-based cognitive behavioral rehabilitation intervention on violent sexual behaviors among sex offenders in Nigerian prisons. Medicine, 98(29), e16103. 
Obiweluozo, P. E., Ede, M. O, Onwurah, C. N., Uzodinma, U. E., Dike, I. C., \& Ejiofor, J. N. (2021). Impact of cognitive behavioural play therapy on social anxiety among school children with stuttering deficit: a cluster randomised trial with three months follow-up. Medicine,100(19), e24350.

Ocak, G., \& Boyraz, S. (2016). Examination of the relation between academic procrastination and time management skills of undergraduate students. Journal of Education and Training Studies, 4(5), 76-84. https://doi.org/10.11114/jets.v4i5.1313

Ogbuanya, T. C., Eseadi, C., Orji, C. T., Anyanwu, J. I., Joachim, O. C., \& Otu, M. S. (2017b). The effect of rational emotive behavior therapy on irrational career beliefs of students of electrical electronics and other engineering trades in technical colleges in Nigeria. Journal of Rational-Emotive \& Cognitive-Behavior Therapy. https://doi.org/10.1007/s10942-017-0282-2

Onyishi, C. N., Ede, M. O., Ossai, O. V., \& Ugwuanyi, C. S. (2020). Rational emotive occupational health coaching in the management of police subjective well-being and work ability: A case of repeated measures. Journal of Police and Criminal Psychology. https://doi.org/10.1007/s11896-019-09357-y

Onwuegbuzie, A. J. (2004). Academic procrastination and statistics anxiety. Assessment \& Evaluation in Higher Education, 29(1), 3-19. https://doi.org/10.1080/0260293042000160384

Omeje, H. O. (2007). Effects of project method on academic achievement and attitude of low ability students in carpentry and joinery. Review of Education, 18(1), 22-33.

Onyechi, K. C. N., Eseadi, C., Okere, A. U., Onuigbo, L. N., Umoke, P. C., Anyaegbunam, N. J., et al. (2016a). Effects of cognitive behavioral coaching on depressive symptoms in a sample of type 2 diabetic inpatients in Nigeria. Medicine, 95(31), e4444. https://doi.org/10.1097/MD.0000000000004444

Ozer, B. U., \& Ferrari, J. R. (2011). Gender orientation and academic procrastination: Exploring Turkish High School Students. Individual Differences Research, 9(I), 33-40.

Pychyl, T. A., Coplan, R. J., \& Reid, P. A. (2002). Parenting and procrastination: Gender differences in the relations between procrastination, parenting style and self-worth in early adolescence. Personality and Individual Differences, 33, 271-285. https://doi.org/10.1016/S0191-8869(01)00151-9

Rothblum, E. D., Solomon, L. J., \& Mavakami, J. (1986). Affective, cognitive, and behavioural differences between high and procrastination. Journal of Counselling Psychology, 33, 338-394. https://doi.org/10.1037/0022-0167.33.4.387

Salman, M. F., Esere, M. O., Omotosho, J. A., Abdullahi, O. E., \& Oniyangi, S. O. (2010). Effect of two psychological techniques in improving academic performance of secondary school students in mathematics. Journal of Modern Mathematics and Statistics, 4(3), 96-100. https://doi.org/10.3923/jmmstat.2010.96.100

Senecal, C., Julien, E., \& Guay, F. (2003). Role conflict and academic procrastination: A self determination perspective. European Journal of School Psychology, 33, 135-145. https://doi.org/10.1002/ejsp.144

Shahnawaz, G. (2016). Procrastination among students: The role of gender, perfectionism and self-esteem. The Indian Journal of Social Work.

Shim, S., \& Ryan, A. (2005). Changes in self-efficacy, challenge avoidance, and intrinsic value in response to grades: The Role of achievement goals changes in self-efficacy, challenge avoidance, and intrinsic value in response to grades: The Role of Achievement Goals. The Journal of Experimental Education, 73(4), 333-349. https://doi.org/10.3200/JEXE.73.4.333-349

Solomon, I. J., \& Rothblum, E. D. (1984). Academic procrastination: frequency and cognitive behavioural collelates. Journal of Counselling Psychology, 31, 503-509. https://doi.org/10.1037/0022-0167.31.4.503

Solomon, L. J., \& Rothblum, E. D. (1984). Academic procrastination assessment scale-students. In M: Hersen and A. S. Ballack (Eds), Dictionary of beahvioural assessment techniques (pp. 358-360). New York: Pergammon Press. https://doi.org/10.1037/t09250-000

Solomon, L. J., \& Rothblum, E. B. (1984). Academic procrastination: Frequency and cognitive behavioural correlates. Journal of Counselling Psychology, 31, 503-509. https://doi.org/10.1037/0022-0167.31.4.503

Steel, P. (2007). The nature of procrastination: A meta-analytic and theoretical review of quintessential self-regulatory facilities. Psychological Bulletin, 133(1), 65-94. https://doi.org/10.1037/0033-2909.133.1.65

Ugwuanyi, C. S., Gana, C. S., Ugwuanyi, C. C., Ezenwa, D. N., Eya, N. M., Ene, C. U., Nwoye, N. M., Ncheke, D. 
C., Adene, F. M., Ede, M. O., Onyishi, C. N., \& Ossai, V. O. (2020a). Efficacy of cognitive behaviour therapy on academic procrastination behaviours among students enrolled in Physics, Chemistry and Mathematics Education (PCME). Journal of Rational-Emotive \& Cognitive-Behavior Therapy. https://doi.org/10.1007/s10942-020-00350-7

Ugwuanyi, C. S., Ede, M. O., Onyishi, C. N., Ossai, O. V., Nwokenna, E. N., Obikwelu, L. C., Ikechukwu-Ilomuanya, A., Amoke, C. V., Okeke, A. O., Ene, C. U., Offordile, E. E., Ozoemena, L. C., \& Nweke, M. L. (2020b). Effect of cognitive-behavioral therapy with music therapy in reducing physics test anxiety among students as measured by generalized test anxiety scale. Medicine, 99, 17(e16406). https://doi.org/10.1097/MD.0000000000016406

\section{Copyrights}

Copyright for this article is retained by the author(s), with first publication rights granted to the journal.

This is an open-access article distributed under the terms and conditions of the Creative Commons Attribution license (http://creativecommons.org/licenses/by/4.0/). 